\title{
CAUSE RELATED MARKETING AND PURCHASE INTENTION CONSUMERS' GOODS IN NEPAL
}

\author{
Jayant Nath Khanal*
}

\begin{abstract}
In an emerging market, social development is an imperative, brands, consumers and society will benefited by cause-related marketing (CRM) that could provide an avenue to those in need receive more support than can be provided by traditional means. Though considerable work on CRM campaigns and consumer responses to them have been undertaken show ever, not much research has been done in this field in Nepal. In this connection, present study attempts to examine consumer responses on CRM, and particularly investigates whether the consumers' level of involvement with a cause and the way in which the message is framed influence purchase intention. This study reveals that cause involvement is significantly influencing factor fir purchase intention while message framing did not. Therefore, there was no interaction between cause involvement and message framing.
\end{abstract}

Key words: Cause-related Marketing; Cause Involvement; Message Framing; Social Cause; Brands, Consumer Involvement; Message Framing.

\section{INTRODUCTION}

Cause-related marketing (CRM) refers a type of marketing which involves the cooperative efforts for profit business along with non-profit organizations. Sometimes, this term is used more broadly to refer to any type of marketing effort for social and other generous causes, including in-house marketing efforts by non-profit organizations. Thus the cause-related marketing differs from corporate giving (philanthropy), as the latter generally involves a specific donation which in fact, is tax deductible, while cause marketing is a marketing relationship not necessarily based on a gift or donation.

The meaning of marketing can precisely be identify as the management processes responsible for identifying, anticipating and satisfying customer or consumer requirements profitably. Marketing involves finding out exact requirements of the customer or consumer and then by providing goods and services for their satisfactions. In essence, this involves providing the best possible marketing mix, i.e. the right goods, at the right time, in the best possible places and with the most desirable level of promotional activities. Today, the term social marketing refer the way in which modern marketing is concerned with meeting the wider needs of the society in which business operates. Social marketing stress on consumers' brand requirements. It also takes into account the needs and expectations of the wider community (Alcaniz, Herrera and Perez, 2009). Cause Related Marketing has become an important ingredient of marketing mix.

Dr. Khanal is an Associate Professor in Padmakanya Multiple Campus, T.U, Baghbazar, Kathmandu, Nepal. 
CRM is a commercial or profitable movement by which businesses and charities or causes form a partnership enterprise, corporation or company with each other for mutual benefits. It is a marketing tool to address the social issues, side to side it provides resources and funding, whilst at the same time addressing important business objectives and goals. It Cause Related is effective works well, everyone wins - the company, the cause and the consumer this is known as a mutually benefited situations.

In other words, it is a joint funding and promotional strategy in which a firm's sales are linked and a percentage of the sales revenue is donated to a charity or other public cause. However, unlike philanthropy, money spent in cause-related marketing is considered an expense and is expected to be a return and come back to the original space.

\section{THE CONCEPT}

The business in the Community (BITC) organization of UK (2004) defines cause-related-marketing as: "A commercial activity by which business and charities or causes from a partnership with each other to market an image, product or service for mutual benefits." Hence following issues could be considered on the basis of above concept:

- $\quad$ CRM involves corporate donation to a charity or cause being contingent on consumer purchase to some extent;

- $\quad$ The consumer is also a partner in the process and derives benefit some kind of from it, if only the satisfaction of making an indirect donation; (Bloom, Hussein and Szykman., 1995).

- $\quad$ The responsibility for CRM activity lies within a company's marketing function.

Cause-related marketing (CRM) is described by the Barone, Miyazaki and Taylor (2000) as a strategy designed to achieve marketing objectives through supporting social causes.

Kotler and Gerald Zaltman (1971) describe Cause-Related-Marketing (CRM) connects a company's contributions to a certain cause, directly or indirectly to participate in profit-driven transactions.

Jocelyn (2008) opines cause-related marketing (CRM) is a mutually beneficial collaboration between a corporation and a nonprofit in which their respective assets are combined to: connect with the consumers, employees, or suppliers, create shareholder and social value, and to communicate the shared values of either organizations or the companies.

This phrase was first used by the American Express with a phrase 'causerelated marketing' in 1983. Its campaign was intended to raise money for the Statue of Liberty's restoration. American Express had donated one cent for the restoration every time someone had are used its charge card. Consequently the number of new cardholders were increased by 45 percent, and card users were increased by 28 percent. 
Some other of cause-related marketing programs are:

- $\quad$ Public awareness campaigns for polio, bird-flue, breast cancer, and other causes

- $\quad$ Requests for small donations for children's charities at the airlines ticket counter, Cinema Hall, Zoo, and Supermarkets checkout

- $\quad$ Licensing of well-known charity trademarks and logos, like World Wildlife Fund's panda.

CRM are not outright gifts to a nonprofit organization rather it is distinct from corporate philanthropy. The corporate dollars involvement are not treated as tax-deductible charitable contributions. Nonprofits potentially benefit from increased fund raising and exposure. Likewise, corporations socially involved in potentially benefit from increased brand loyalty and employee morale. For products of similar quality consumers will consider the company's image and reputation when choosing a brand. For the development of CRM opportunities, nonprofit organizations should expand their research efforts beyond traditional corporate directories and refer to resources in the business departments of public or academic libraries.

CRM involves a commercial transaction from the consumers' side. The company with CRM does not give towards the cause unless the consumer engages in a revenue-providing exchange with the company whereas with the sponsorship company gives hope that will induce a positive consumer reaction. Brands use CRM influences consumers choice by capitalizing on the halo effect of associating with a cause and in essence borrow from the equity and goodwill of these causes. The extent of this influence has tied to a number of variables including the fit of the cause to the brand, the level of involvement of the purchase decision and the price premium perception. It is further highlighted that, in terms of decision-making process, the positive influence of bundling charity donations with products and how this offers consumers two distinctive positive outcomes called affect-based complimentarily (Barone, Miyazaki and Taylor, 2000).

CRM also assists consumers to distinguish between responsible and nonresponsible organizations and therefore aids the consumer's decision-making process in making advertising none effective for instance the inclusion of a cause claim in a message significantly increases unaided recall of an advertisement.

Regardlessly the advertisement includes a CRM message of how good the fit between the cause and the brand, the consumers have a more positive response to a brand. Furthermore, when consumers have high brand consciousness, the brand/cause fit becomes more relevant. Different results have been found in other studies indicating that consumers' attitudes to brands are unaffected by the CRM message. This suggests that the presence of a CRM message does not necessarily influence the consumers' evaluation of a product or brand (Grau and Folse, 2007). 


\section{CONSUMER INVOLVEMENT WITH THE CAUSE AND MESSAGE FRAMING}

The level of involvement a consumer has with the cause and how the message is communicated are two key factors in CRM. The consumer involvement accounts for the differences in the degree of mental and physical effort a consumer is willing to devote to consumption-related activities. An important aspect of CRM is the level of involvement a consumer has with the cause which is attached to the brand. The more positive consumer response is to CRM, the more important a cause is to a consumer, One can argue that the level of involvement a consumer has with the cause influences the intensity with which a consumer will process a charity marketing message from a brand which is associated with the cause. A high level of involvement with the cause translates into a more intense interpretation of the message and higher likelihood to participate. CRM can be defined involvement as 'a person's perceived relevance of the advertisement based on inherent needs, values, and interests' in advertising and CRM campaigns. Based on the literature, it is, therefore, proposed that the degree of familiarity or involvement with a cause or charity is a key influencer of CRM.

The message framing is also an important factor to be implemented wisely and practically. Some researchers argue that the negative framing to improve outcomes and others support that the positive framing is more effective so as to improve the outcomes. Consumers with low cause involvement are more inclined to respond to messages which are framed positively and communicate gains as opposed to highly involved consumers who respond more to risk avoidance type messages that is, negatively framed messages. As a result the immediacy of the cause also influenced a consumer's response. A message framed to address a problem such as a natural disaster, for example, was more positively received than one supporting an ongoing cause rather outgoing the clusters in the negative way to opposed the highly involve messages. Thus it is found and realized that the relatively limited research has been done in the realm of CRM criteria for a successful campaign.

It is found that race had some influence on how consumers perceived messages and realized that some whites hold residual guilt from Mangols and Brahmins while successful black females of Terai region feel especially guilty about their success when compared with many of their less successful counterparts. These convey the message feelings guilty that respondents were more responsive to messages which in fact and in some way allowed them to alleviate some of this guilt by doing something positive for those less fortunate. It is possible that these societal idiosyncrasies may in fact lead to different results compared with what obtains in other countries. This study therefore investigates how both cause involvement and message framing react and interact with each other. Hence the expected result is positive message framing is more effective for low-involvement consumers, but given the inherent guilt present, positive framing may also be preferred by high-involvement consumers.

\section{UNDERSTANDING CHARITABLE GIVING}

The CRM can, without any hassle work and also important to understand charitable giving and the factors that influence how charitable an individual may 
be. Charitable giving is described as a process of exchange involving both economic and social values performed for both selfish and altruistic motives. With the income levels involvement, the factors which influence charitable giving include income levels. Higher levels of income and wealth lead to higher absolute levels of charitable donations and the gifts. The effect of income on the propensity to donate or the relative proportions of income donated are conflicting. For example, some findings indicate that not very often but in sometimes, the highest and lowest income earners tend to give the greatest proportions of their incomes to charity. Other studies suggest that there is a negative relationship between income level and charitable giving. However, some researchers argue that charitable giving does not depend on one's class, education, language, race or color, but is linked to the cultural environment and may be subject to sequential, temporal and geographic variation. Therefore, there are many variables which need to be considered when evaluating the decisions process and propensity to donate, including but not limited to, how charities ask for support, what media is used, how strong the brand of the charity is and the demographics of the target market.

\section{OBJECTIVES}

Following are the objectives of the study:

- To determine the influence of a cause message framed to induce feelings of guilt (negatively framed message) and a cause message framed to induce positive feelings,

- To examine the cause message framed interacts with cause involvement,

- To reemphasize the context of the CRM campaign,

- To investigate the more positive consumer response to CRM, and

- To find out the races of influence to perceived messages and realization of framing.

\section{RESEARCH HYPOTHESES}

Following hypotheses are tested in the study:

$\mathbf{H}_{1}$ : There is high cause involvement influences purchase intention positively.

$\mathbf{H}_{2}$ : Consumers with low cause involvement respond more positively to CRM messages framed positively.

\section{METHODOLOGY}

Two independent variables namely cause involvement and message framing and one dependent variable, purchase intention are considered in the study. Each of these independent variables had two levels, hence the 2 (number of independent variables) $\times 2$ (levels of each variable) design (Meyerowitz and Chaiken, 1987).

The brand (Hamlin, and Wilson, 2004) used for the purpose is CG (Chaudhary Group), a reputed brand within the Country Nepal particularly for fast-moving-consumer-goods (FMCG) market is.

The reasoning of consideration to Chaudhary Group (CG) could be rationalize that this is the pioneer foods company that has been in existence for more than two decades and has enjoyed significant market share for the duration of its existence. CG has been chosen as the brand for investigation because it has 
a strong heritage in the Nepali market and is well known to consumers. This avoids variations occurring due to lack of brand knowledge or experience with the brand (Lafferty and Goldsmith, 2005). CG is also a brand that provides fast moving consumer goods which are low-involvement purchases and by focusing on low involvement products it is possible to remove the influence of decision processes which may differ between high and low involvement purchases. It is obvious that brand and cause fit are important when designing CRM campaigns. For this reason, a food-related cause was used in the form of a feeding scheme which provides fast-food focusing to the school and $10+2$ students. For every pack of CG WaiWai purchased, a small donation would be made towards a fictitious and handicapped i.e. underprivileged and deprived children's feeding scheme.

\section{SAMPLING AND RESPONDENTS}

The samples basically of foods, beverages and the brewery of Chaudhary Group were collected so as to make the analysis of consumer's choice and the preferences on brands and tastes of goods. They are;

As well integrated, self-contained FMCG industry set up by Chaudhary Group has evolved to become one of Nepal's leading manufacturers of FMCG products. $\mathrm{CG}$ has interests across a variety of FMCG product brands like; Food and Beverages, Beer and Cigarettes. It has the following divisions under FMCG.

CG Foods (Nepal) Pvt. Ltd. (CGFN) is an ISO 9001:2008 certified company manufacturing instant noodles increased its product portfolio to Extruded Snacks, Potato Chips, Fried Snacks, Fruit Drinks, Chocolate Enrobed Wafer and Broken Noodles popularly known as Bhujiya. CGFN has two manufacturing locations in Nepal which have been named as FUDCO at Kathmandu and Chaudhary Udyog Gram (CUG) at Nawalparasi, $160 \mathrm{Kms}$. south west of Kathmandu.

Confectionaries- the Zoom wafers are available in four Different flavors namely, Chocolate Enrobed Wafer, Vanila Flavour Wafer, Orange Flavour Wager and Orange Flavour Wafer. It contains Sugar, Vegetable Fat, Wheat Flour, Milk Powder and Sodium Bicarbonate.

As beverages, CG Gold Beverage Nepal (GBN) produces of fruit juice of popular flavours like Alfanso Mango, Mixed fruit, and Pineapple under its brand name Rio.

Since the women are typically the shoppers within a household, the research focused on women as data show that the primary target market for CG is women. Quota sampling was used as the probability of one of these women being chosen is not known. Relevant shopping centres (strata) that cater for the brand target market within the major cities of the Country (Nepal) were identified and individuals were selected using a simple random sampling technique.

Starting from the time the interviewer was at the mall entrance, every fifth to ten female was approached. Each interviewer was given either only the negatively framed stimulus (A print advertisement featuring an image of a box of CG foods- WaiWai (i.e. a nation lead Chaumin became popular among school childrens) with the message "Yeti Tasty Teti Healthy" And Childrens should not go hungry in Tiffin time in school if carry one pkt of WaiWai that is why 
buy CG WaiWai and the company will put your coupon on lottery or buy 12 pkts of WaiWai and get one spontaneously. Every pack you buy means a child does not go hungry or the positively framed stimulus. So, buy CG WaiWai and we will donate one pkt. for every pack (dozen) you buy. Every pack you buy helps to win one pkt of WaiWai) in order to ensure simplicity.

The sample size which was initially selected consisted of $n=20$ for each cell of the $2 \times 2$ factorial ANOVA matrix. However, the sample size realized was 10 cases per cell distribution (Table 1 );

Table 1: 2 X2 Factorial ANOVA Matrix

\begin{tabular}{|c|c|c|c|}
\hline Involvement & \multicolumn{3}{|c|}{ Message framing } \\
\hline & Negative & Positive & Total \\
\hline Low & 10 & 10 & 20 \\
\hline High & 10 & 10 & 20 \\
\hline Total & 20 & 20 & 40 \\
\hline
\end{tabular}

\section{TOOLS}

To establish cause involvement, a 20-item seven-point semantic differential scale was used based on previous work with adaptations from the Personal Involvement Inventory (PII) scale. This scale asked respondents to indicate whether the cause in the campaign is (Gupta and Pirsch, 2006): Unimportant or Important, Means nothing or Means a lot, is personally relevant or is not personally relevant, Matters a great deal or Does not matter a great deal, is of concern or is of no concern, and so forth. The positive and negative statements varied in position from left to right to avoid a tendency to only read the adjective placed on the left. The PII scale was tested for validity and reliability. The $\alpha$ of 0.93 realized is comparable with the reported average of 0.95 to 0.97 of the 20 -item PII scale used indicating that the scale is reliable. Validity was checked using the 'corrected item-total correlation' and exceeded the 0.3 minimum is suggested for all items used in the scale.

Cause involvement was only determined after being measured because it was not possible to assign respondents to cells (high or low involvement) a priori. A middle point was assigned based on the data gathered in order to separate respondents into these categories. The data provided sufficient information to provide 10 high involvement and 10 low involvement respondents using this technique. Respondents with total involvement scores of greater than 32 were assigned to lower involvement and those less than 32 were assigned to higher involvement. Respondents were randomly assigned to positively and negatively framed campaigns in order to avoid the influence of having to choose between the positive and negative campaign as this would influence results. The negatively framed message was designed to induce feelings of guilt while the positively framed message was designed to focus the positive contribution the respondent can make (Meyerowitz and Chaiken, 1987). The advertisements were pre-tested with 10 randomly selected subjects not participating in the study to ensure that the campaign messages communicated as desired. 


\section{RESULTS AND DISCUSSION}

The existence of interaction between the independent variables was assessed, before testing for the main effects. As reflected in Hypotheses 2 was expected based on previous research. An examination of the profile plot of the results (Figure 1) suggested the existence of interaction between level of involvement and message framing due to the non-parallel lines. However, the results in show that there is in fact no interaction between level of involvement and message framing with regard to influence on purchase propensity $[F(1$, $67.8)=0.212, P=0.648]$ (Table 2). Hypotheses 2 is therefore rejected. Further, the $R^{2}$ value $(0.113)$ (Table 2$)$ is relatively small indicating that some other factors account for the majority of the variance observed. This is contrary to findings that higher involved respondents responded better to negatively framed messages and lower involved respondents had responded better to positively framed messages.

\section{Figure 1}

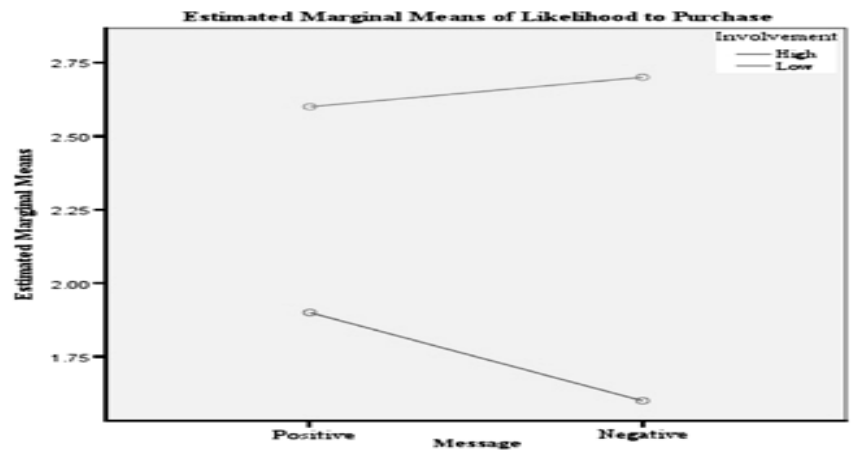

Table 2: Two-way ANOVA Results

\begin{tabular}{|l|c|c|c|c|c|c|}
\hline \multicolumn{7}{|c|}{ Tests of between-subjects effects } \\
\hline \multicolumn{7}{|c|}{ Dependent variable: Purchase intention } \\
\hline $\begin{array}{c}\text { Type III } \\
\text { sum of } \\
\text { squares }\end{array}$ & df & $\begin{array}{c}\text { Mean } \\
\text { square }\end{array}$ & F & Sig. & Partial $\boldsymbol{\eta}^{2}$ \\
\hline Corrected Model & 8.600 & 3 & 2.867 & 1.522 & 0.225 & 0.113 \\
\hline Intercept & 193.600 & 1 & 193.600 & 102.796 & 0.000 & 0.741 \\
\hline $\begin{array}{l}\text { Level of } \\
\text { Involvement }\end{array}$ & 8.100 & 1 & 8.100 & 4.301 & 0.045 & 0.107 \\
\hline Message & 0.100 & 1 & 0.100 & 0.053 & 0.819 & 0.001 \\
\hline $\begin{array}{l}\text { Level of } \\
\text { Involvement } \\
* \text { Message Framing }\end{array}$ & 0.400 & 1 & 0.400 & 0.212 & 0.648 & 0.006 \\
\hline Error & 67.800 & 36 & 1.883 & - & - & - \\
\hline Total & 270.000 & 40 & - & - & - & - \\
\hline Corrected Total & 76.400 & 39 & - & - & - & - \\
\hline
\end{tabular}

${ }^{a} R^{2}=0.113$ (Adjusted $R^{2}=0.039$ ). 
Although there is no interaction between the independent variables, there is a main effect caused by level of involvement $[F(1,67.8)=0.4 .301, P=0.045]$. Hence the level of involvement with a cause influences purchase intention. Hypothesis 1 is therefore not rejected $(P=0.045)$. However, the effect size (that is, partial $\eta^{2}=0.107$ ) caused by involvement is moderate according to Cohen's (1988) criteria. There is no main effect for message framing $[F(1,67.8)=0.053, P=0.819]$, meaning that message framing did not influence purchase intention in the study.

\section{CONCLUSION and RECOMMENDATIONS}

It is imperative to understand what factors influence the success of CRM campaigns and how these are perceived by considering the growing importance of CRM in emerging economies that face many social issues (Kotler and Zaltman, 1971).

CRM; specifically how their level of involvement with a cause and how the CRM message is framed influenced their intention to purchase. Contrary to our expectations, the study reveals that consumers with low cause involvement did not respond more positively to CRM messages framed positively; and that consumers with high cause involvement did not respond positively to messages framed negatively (Nan and Heo, 2007). Only the level of involvement influenced intention to purchase.

The CRM campaign is an important factor. While giving back to society, being able to tailor a CRM campaign towards a defined audience can therefore be used to differentiate a brand and to build brand equity. Based on this study, it appears that cultivating consumer involvement (Sen and Bhattacharya, 2001) with a cause is more likely to yield positive results i.e., intention to purchase rather than just focusing on the message. Therefore marketing effort should be directed at igniting and growing consumer involvement with social causes in order to maximize impact and campaign success.

\section{WORKS CITED}

Alcaniz, E.B., Herrera, A.A. and Perez, R.C. (2009). "Epistemological Evolution of Corporate Social Responsibility in Marketing." International Review on Public and Nonprofit Marketing. 6(1), 35-50.

Barone, M.J., Miyazaki, A.D. and Taylor, K.A., (2000). "The influence of causerelated marketing on consumer choice: Does one good turn deserve another?" Journal of the Academy of Marketing Science, 28(2), 248-262.

Bloom, P.N., Hussein, P.Y. and Szykman, L.S., (1995). "Benefiting society and the bottom line." Marketing Management. 4(3), 8-18.

Grau, S. and Folse, J.G. (2007). "Cause-related marketing (CRM): The influence of donation proximity and message-framing cues on the less-involved consumer." Journal of Advertising. 36(4): 19-33.

Gupta, S. and Pirsch, J., (2006). "The company-cause-customer fit decision in cause-related marketing." Journal of Consumer Marketing. 23(6), 314326. 
Kotler P., and Gerald Zaltman,(1971). "Social Marketing: An Approach to Planned Social Change." Journal of Marketing, July 1971, Vol. 35, Issue 3 , pp. 3-12.

Lafferty, B. and Goldsmith, E. (2005). "Cause-brand alliances: Does the cause help the brand or does the brand help the cause?" Journal of Business Research. 58(4), 423-429.

Meyerowitz, B. and Chaiken, S. (1987). "The effect of message framing on breast self-examination attitudes, intentions and behaviours." Journal of Personality and Social Psychology, 52(3), 500-510.

Nan, X. and Heo, K. (2007). "Consumer responses to corporate social responsibility (CSR) initiatives: Examining the role of brand-cause fit in cause-related marketing." Journal of Advertising. 36(2), 63-74.

Sen, S. and Bhattacharya, C., (2001). "Does doing good always lead to doing better? Consumer reactions to corporate social responsibility." Journal of Marketing Research, 38(2), 225-243. 